\title{
POTENSI ACETOBACTER XYLINUM DALAM PEMBUATAN NATA DE SYZYGIUM
}

\author{
Sri Wahyuni ${ }^{1)}$ Jumiati $^{2)}$, \\ ${ }^{1) 2)}$ Program Studi Pendidikan Biologi, FKIP Universitas Lancang Kuning \\ email $^{1)}$ : sriwahyunifkip@unilak.ac.id
}

\begin{abstract}
ABSTRAK: Pembuatan Nata de sygyzium adalah makanan hasil fermentasi bakteri Acetobacter xylinum yang memiliki tekstur kenyal, transparan dan lembut. Jambu air dapat dijadikan media dalam pembuatan nata karena sebagai sumber karbohidrat yang baik bagi pertumbuhan bakteri. Penelitian ini bertujuan untuk menentukan potensi Acetobacter xylinum nata de syzygium terbaik. Jenis penelitian ini adalah true eksperimen (murni) dengan menggunakan Rancangan Acak Lengkap (RAL) dengan dua ulangan. Pengambilan sampel dilakukan secara purpossive random sampling. Penelitian dilaksanakan bulan Maret-Oktober 2019 di Laboratorium pendidikan Biologi Universitas Lancing Kuning. Perlakuan yang digunakan adalah potensi bakteri dilihat dari perbedaan konsentrasi bakteri Acetobacter xylinum $(5 \%, 10 \%, 15 \%, 20 \%, 25 \%)$. Parameter yang dianalisis meliputi analisis fisik berat basah, berat kering, $\mathrm{pH}$ kadar air, warna, aroma, tekstur. Berdasarkan hasil penelitian konsentrasi Acetobacter $20 \%$ memberikan perolehan nata yang paling baik dengan berat basah 144,5 g; berat kering 60,35 g, pH 3, kadar air 58,23\% dan memiliki tekstur yang padat dan kenyal serta berwarna putih.
\end{abstract}

\section{Kata kunci: Potensi Acetobacter xylinum, nata de syzygium, jambu air}

ABSTRACT: Nata de sygyzium is a fermented food of Acetobacter xylinum which has a chewy, transparent and soft texture. Guava can be used as a media in making nata because it is a good source of carbohydrates for bacterial growth. This study aims to determine the best potential of Acetobacter xylinum for making nata de syzygium. This type of research was true experiment by using a completely randomized design (CRD) with two replications. Sampling was done by purposive random sampling. The study was conducted in March-October 2019 in the Biology Education Laboratory of Lancang Kuning University. The treatment used was the potential for bacteria seen from the difference in the concentration of Acetobacter xylinum (5\%, 10\%, 15\%, 20\%, 25\%). Parameters analyzed included physical analysis of wet weight, dry weight, $\mathrm{pH}$, moisture content, color, aroma, texture of nata de syzygium. Based on the research results, the concentration of Acetobacter $20 \%$ gives the best nata acquisition with a wet weight of $144.5 \mathrm{~g}$; dry weight $60.35 \mathrm{~g}, \mathrm{pH} \mathrm{3,} \mathrm{moisture} \mathrm{content} 58.23 \%$ and has a dense and chewy texture and white.

Key words: Potential Acetobacter xylinum, nata de syzygium, guava

PENDAHULUAN

Indonesia kaya buah-buahan tempatan (local) yang memiliki khasiat dan manfaat bagi kehidupan manusia. Salah satu buah yang melimpah di Indonesia dan berbuah sepanjang tahun 
yaitu jambu air. Jambu air banyak jenisnya, salah jambu air yang perlu menarik perhatian pada saat ini adalah jambu air lokal (Syzygium aqueum) yang berlimpah ketika panen. Masa panen yang singkat menyebabkan jambu air banyak yang jatuh, busuk dan tidak dimanfaatkan oleh kebanyakan masyarakat. Jambu dibiarkan terbuang percuma, padahal jambu air tersebut kaya manfaat ini sangat disayangkan jika tidak dijadikan suatu yang bermanfaat. Manfaat jambu air salah satunya yaitu menjadi bahan makanan yang banyak mengandung karbohidrat (gula) yang dapat dijadikan bahan nata.

Nata merupakan makanan yang mengandung selulosa yang dibentuk oleh fermentasi bakteri Acetobacter xylinum. Pengembangan produk nata diperkirakan mempunyai prospek yang cerah di masa mendatang daripada

\section{METODE PENELITIAN}

Jenis penelitian yang dilakukan adalah eksperimen murni atau True Eksperiment. Variabel terikatnya adalah ketebalan nata, tekstur nata, dan rasa dari nata. Sedangkan variabel kontrolnya adalah konsentrasi Acetobacter mulai dari 5\%, 10\%, 15\%, $20 \%$ dan 25\%. Penelitian ini menggunakan metode rancangan acak lengkap dengan 5 perlakuan dan 2 kali ulangan. hanya menjadi limbah yang kurang bermanfaat. Berdasarkan observasi yang telah dilakukan biasanya panen jambu air yang berlimbah terbuang begitu saja menjadi limbah, tidak ada solusi untuk mengolah menjadi sesuatu yang bermanfaat. Terutama bahan bakunya merupakan limbah buah-buahan lokal yang mudah didapat dan menemukannya tidak memerlukan biaya. Dengan potensi Acetobacter xylinum, limbah jambu air dapat dijadikan nata Syzygium. Pada Penelitian ini akan mencoba membuat nata dengan jambu air lokal semua bagian buahnya yang biasanya banyak yang busuk dan dibuang sia-sia.

Tujuan penelitian ini adalah untuk mengetahui potensi Acetobacter dalam pembuatan nata de syzygium dan menentukan konsentrasi Acetobacter yang optimum ditambahkan untuk membuat nata jambu.

Sampel yang digunakan dalam penelitian ini adalah jambu air lokal yang diperoleh di Kota Pekanbaru. Dalam penelitian ini pengambilan sampel dilakukan secara purpossive sampling yang didasarkan atas pertimbangan peneliti sendiri dengan kriteria buah masih dalam keadaan segar (belum busuk).

Kegiatan penelitian dilakukan

dari bulan Maret-Oktober 2019, 
bertempat di Laboratorium Pendidikan Biologi Universitas Lancang Kuning.

Instrumen yang digunakan dalam penelitian ini meliputi seperangkat alat dan bahan. Peralatan yang digunakan terdiri dari :
a. Oven / Autoclave
b. Eksikator
c. Neraca Analitik
d. Blender / juicer
e. Toples
f. Panci
g. $\mathrm{pH}$ meter
h. Beaker Glass $100 \mathrm{~mL}, 500 \mathrm{~mL}$
i. Tabung Reaksi
j. Gelas Ukur $500 \mathrm{~mL}$
k. Pipet volume $10 \mathrm{~mL}$
1. Erlenmeyer
m. Kain Saring, kertas saring
n. Kompor

Bahan-bahan yang digunakan adalah :

a. Jambu air lokal

b. Bakteri Acetobacter xylinum

c. Aquades

d. Urea

e. Gula pasir (sukrosa)

f. air kelapa

g. Cuka makan

h. kertas Lakmus.

Pengumpulan data dilakukan untuk mendapat data berupa berat nata basah, berat nata kering / bersih, pH, tekstur (kekenyalan) dan aroma.
Teknik Analisis Data meliputi :

a. Analisis Kuantitatif meliputi tekstur nata dan aroma yang terbentuk dari nata de jambu.

b. Analisis kualitatif meliputi berat basah, berat kering, dan $\mathrm{pH}$ pada nata

c. Pembuatan Nata

Seluruh bagian buah jambu air lokal diambil dan dibersihkan. Buah ditimbang sebanyak $3 \mathrm{~kg}$, kemudian ditambahkan air dengan perbandingan $1: 5$, diblender sedikit demi sedikit sesuai kapasitas blender sampai halus dan tercampur sempurna dalam air. Selanjutnya disaring dengan kain penyaring sedikit demi sedikit sambil sekali-kali diperas ampasnya agar seluruh filtrat dapat terambil. Sebanyak 10 Liter filtrate dimasukkan ke dalam panci, lalu dididihkan di atas kompor. Ketika mendidih ditambahkan gula pasir, urea, cuka, sambil diaduk-aduk agar larut dengan sempurna. Setelah itu diangkat, didinginkan, dituang dalam 20 wadah (@ $500 \mathrm{~mL}$ ) yang sudah disterilisasi (dituangi air mendidih sebelum digunakan), sisanya digunakan untuk menanam starter. Tutup dengan kertas sampai benar-benar dingin. Setelah dingin, ditambahkan masing-masing 5\%, $10 \%, \quad 15 \%, 20 \%$ dan $25 \%$ starter Acetobacter xylinum. Fermentasi selama 14 hari. Setelah 14 hari dilakukan 
pemanenan. Setiap perlakuan di ukur PHnya dengan kertas lakmus, dilihat tekstur atau kekenyalannya dengan cara disentuh, dilakukan uji aroma dengan organ penciuman, ditimbang berat

\section{HASIL PENELITIAN}

basahnya. Setelah berat basah didapat semua perlakuan di Oven selama 24 jam, setelah itu akan didapat berat kering dan dapat dihitung kadar air nata.

Berdasarkan hasil penelitian yang telah dilakukan didapat data hasil penelitian sebagai berikut;

A. Data Hasil Analisa Tekstur (Kekenyalan), Aroma dan Warna Nata de syzygium

Tabel 1. Hasil Analisis Tekstur (Kekenyalan), Aroma dan Warna Nata de syzygium

\begin{tabular}{|c|c|c|c|}
\hline Perlakuan & Tekstur & Aroma & Warna \\
\hline $5 \%$ & $\begin{array}{c}\text { Tipis, Tidak } \\
\text { kenyal }\end{array}$ & Tidak bau & Coklat tua \\
\hline $10 \%$ & Padat Kenyal & Asam (++) & Putih kekuningan \\
\hline $15 \%$ & Padat Kenyal & Asam kuat (++) & Putih \\
\hline $20 \%$ & Padat tebal Kenyal & Asam kuat $(+++)$ & Putih \\
\hline $25 \%$ & Kenyal & Busuk & Putih \\
\hline
\end{tabular}

Dari data di atas terlihat bahwa tekstur dari nata yang terbentuk selama 14 hari fermentasi terlihat bahwa pada sampel 5\% teksturnya tipis dan tidak kenyal, sedangkan pada sampel 10\%, 15\%, 20\% dan $25 \%$ teksturnya kenyal. Data analisis aroma (bau) terlihat bahwa pada sampel $5 \%$ tidak berbau, sedangkan pada kosentrasi $10 \%$, $15 \%$ dan $20 \%$ berbau Asam. Pada sampel 25\% berbau busuk. Semakin tinggi konsentrasi Acetobacter meyebabkan aroma asam yang semakin kuat dan berbau. Acetobacter sebagai Bio-Lectura: Jurnal Pendidikan Biologi, Vol 6, No 2, Oktober 2019 bakteri asam laktat, selama proses fermentasi menghasilkan asam laktat sebagai metabolit hasil perombakan glukosa. Semakin banyak Acetobacter yang digunakan semakin tinggi kemampuan menghasilkan asam laktat sehingga menimbulkan bau asam yang kuat pula. Analisis warna yang terlihat dalam tabel di atas sampel 5\% dan 25\% warna yang terbentuk coklat tua dan pada sampel $10 \%$ warna putih kekuningan. Sedangkan warna putih terdapat pada sampel $15 \%$ dan 20\%. Warna putih 
transparan dan kenyal yang dihasilkan merupakan hasil fermentasi bakteri $A$. xylinum. Hal ini sesuai dengan pendapat Nainggolan, 2009 yang menyatakan bahwa Bakteri Accetobacter xylinum menghasilkan enzim ekstraseluler yang dapat menyusun (mempolimerisasi) zat gula (glukosa) menjadi ribuan rantai (homopolimer) serat atau selulosa. Dari jutaan jasad renik yang tumbuh dalam media, akan dihasilkan jutaan lembar benang-benang selulosa yang akhirnya Nampak padat berwarna putih hingga transparan, yang disebut sebagai nata yang termasuk metabolit sekunder.

B. Data Hasil Analisa Berat Basah, Berat Kering, pH dan Kadar Air Nata de syzygium

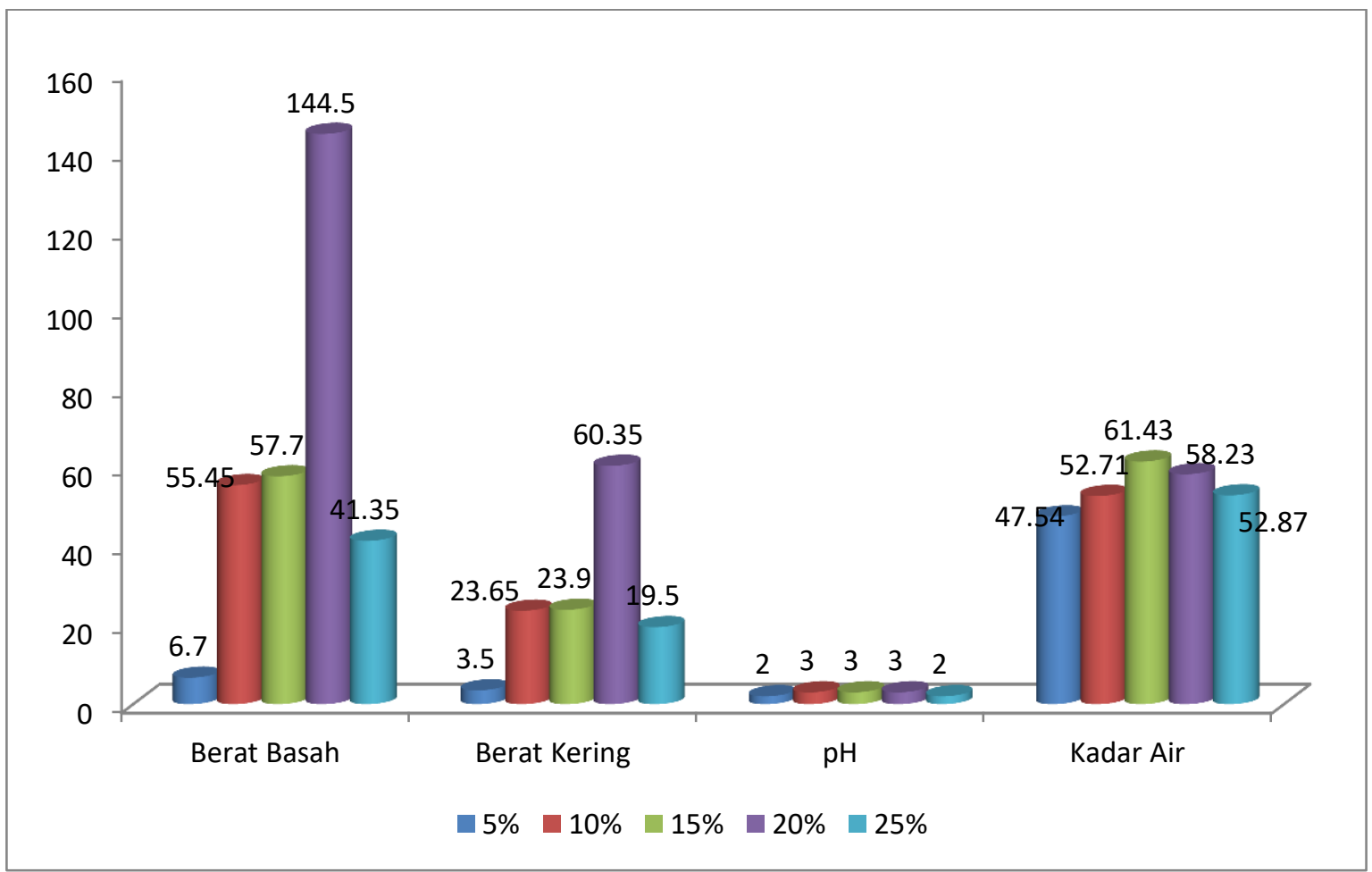

Gambar 1. Grafik Pengukuran Berat Basah, Berat Kering, pH dan Kadar Air Nata de syzygium

Berdasarkan hasil penelitian didapatkan berat basah terendah pada sampel 5\% yaitu rerata sebesar 6,7 gram dan berat paling tinggi pada perlakuan $20 \%$ yaitu 144,5\%. Semakin tinggi konsentrasi Acetobacter semakin tinggi berat basah nata yang dihasilkan. Tetapi pada perlakuan $25 \%$ perolehan berat basah nata menunjukkan penurunan. Berdasarkan data pada table di atas, konsentrasi terbaik Acetobacter untuk volume media ekstrak jambu yang 
berjumlah $500 \mathrm{~mL}$ yaitu sebesar $20 \%$. Pada konsentrasi Acetobacter 25\% kemungkinan selama fermentasi Acetobacter mengalami fase kematian (death phase), disebabkan kurangnya nutrisi. Semakin banyak Acetobacter tentu memerlukan konsentrasi glukosa yang tinggi. Sedangkan pada konsentrasi Acetobacter yang kurang dari $20 \%$ belum cukup optimal untuk mampu mengubah glukosa selama proses fermentasi menjadi nata.

Hasil analisa berat kering didapat hasil seperti terlihat dalam tabel di atas yang terendah pada perlakuan $5 \%$ dan yang paling tertinggi pada perlakuan 20\%. Berat kering diperoleh dari pengeringan nata selama 24 jam di dalam oven dengan suhu $105^{\circ} \mathrm{C}$. Berat kering berkorelasi dengan berat basah.

Berdasarkan hasil analisis data pengukuran $\mathrm{pH}$ dengan menggunakan kertas lakmus didapat hasil rerata setiap perlakuan yaitu pada sampel 5\% dan $25 \%$ yaitu 2 sedangkan perlakuan yang lainnya didapat $\mathrm{pH}$ yaitu 3. Perbedaan konsentrasi Acetobacter tidak terlalu mempengaruhi tingkat keasaman media. Berdasarkan hasil penelitian pengukuran kadar air, perlakuan konsentrasi starter Acetobacter $15 \%$ memberikan kadar air tertinggi sebesar $61,43 \%$ dan kadar air terendah pada perlakuan $5 \%$ yaitu sebesar $47,54 \%$. Kadar air berkorelasi terhadap berat basah dan berat kering nata. Semakin tinggi berat basah dan semakin rendah berat kering akan menghasilkan kadar air yang semakin tinggi.

\section{Hasil Uji Anova}

Hasil analisisi uji anova untuk berat basah, berat kering, $\mathrm{pH}$ dan kadar air nata disajikan pada table berikut :

Tabel 4.8. Rekapitulasi Hasil Analisis Anova

\begin{tabular}{|c|c|c|c|c|}
\hline Parameter & F Hitung & Sig & Taraf & Keterangan \\
\hline Berat Basah & 502.553 & 0.000 & 0.05 & Berbeda signifikan \\
\hline Berat Kering & 409.111 & 0.000 & 0.05 & Berbeda signifikan \\
\hline $\mathrm{pH}$ & - & - & 0.05 & Tidak Berbeda signifikan \\
\hline Kadar Air & 60.133 & 0.000 & 0.05 & Berbeda signifikan \\
\hline
\end{tabular}

Berdasarkan tabel di atas, perbedaan konsentrasi Acetobacter memberikan hasil yang berbeda signifikan terhadap berat basah, berat kering dan kadar air nata yang dihasilkan, sedangkan $\mathrm{pH}$ tidak berbeda signifikan.

Tabel 4.9. Rekapitulasi Hasil Analisis Duncan 


\begin{tabular}{|c|c|c|c|c|}
\hline Perlakuan & Berat Basah $(\mathbf{g})$ & Berat Kering (g) & $\mathbf{p H}$ & Kadar Air (\%) \\
\hline $5 \%$ & $6,7^{\mathrm{a}}$ & $3,5^{\mathrm{a}}$ & $2^{\mathrm{a}}$ & $47.54^{\mathrm{a}}$ \\
\hline $10 \%$ & $55,45^{\mathrm{c}}$ & $23,65^{\mathrm{c}}$ & $3^{\mathrm{a}}$ & $52.71^{\mathrm{b}}$ \\
\hline $15 \%$ & $57,70^{\mathrm{c}}$ & $23,90^{\mathrm{bc}}$ & $3^{\mathrm{a}}$ & $61.43^{\mathrm{d}}$ \\
\hline $20 \%$ & $144,5^{\mathrm{d}}$ & $60,35^{\mathrm{d}}$ & $3^{\mathrm{a}}$ & $58.23^{\mathrm{c}}$ \\
\hline $25 \%$ & $41,35^{\mathrm{b}}$ & $19,50^{\mathrm{b}}$ & $2^{\mathrm{a}}$ & $52.87^{\mathrm{b}}$ \\
\hline
\end{tabular}

\section{Catatan : huruf yang sama di dalam satu kolom artinya tidak berbeda signifikan pada taraf $5 \%$}

\section{KESIMPULAN}

Berdasarkan hasil penelitian ini dapat disimpulkan bahwa jambu air memiliki potensi yang cukup baik sebagai media pembuatan nata pengganti air kelapa dengan menggunakan bakteri asam laktat

\section{DAFTAR PUSTAKA}

Agung S. Bakti. (1986). Penggunaan Nira Kelapa, Nira Aren, dan Tetes Tebu pada Fermentasi Nata De Coco. Teknologi Pertanian UGM; Yogyakarta.

Anggrawati, Pratiwi Sri dan Zelika Mega Ramadhania. (2014). Kandungan Senyawa Kimia dan Bioaktivitas dari Jambu Air (Syzygium aqueum Burn. f. Alston). Fakultas Farmasi, Universitas Padjadjaran. Jurnal Farmaka Suplemen. Volume 14 Nomor 2 hal. 331

Cahyono, Bambang. (2010). Sukses

Budidaya Jambu Air Di

Pekarangan Dan Perkebunan.

Andi Publisher. Yogyakarta.

Esa, Faezah, Siti Masrinda Tasirin, Norliza Abd Rahman. (2014). Overview of Bacterial Cellulose Production and Application.
Acetobacter. Untuk volume media 500 $\mathrm{mL}$, konsentrasi Acetobacter yang optimal dalam memproduksi nata adalah sebesar 20\% dengan perolehan berat basah nata tertinggi sebesar $144,5 \mathrm{~g}$.

Jurnal Agriculture and Agricultural Science Procedia 2 (2014) 113- 119 2210-7843. Published by Elsevier B.V.

Gassner, G.Hawley. (1977). The Condensed Chemical Dictionary. New York : Van Nostrand Rein Hold Company.

Halib, Nadia. Mohd, Cairul Iqbal. Mohd, Amin \& Ishak Ahmad. Physicochemical Properties and Characterization of Nata de Coco from Local Food Industries as a Source of Cellulose (Sifat Fizikokimia dan Pencirian Nata de Coco daripada Industri Makanan Tempatan Sebagai Sumber Selulosa). Jurnal Sains Malaysiana. 41(2)(2012): 205211

Hanifa, Hadyani Millati dan Sri Haryanti. (2016) Morfoanatomi Daun Jambu Air (Syzygium 
samarangense) var. Demak Normal dan Terserang Hama Ulat Morfoanatomy Normal Leaf and Infected Pest Leaf of Water Guava (Syzygium samarangense) var. Demak. ejournal2.undip.ac.id. Volume 1 Nomor 1.

Hardiantono, B. (1992). Pedoman Praktis Budidaya Tanaman Jambu. PD Mahkota; Jakarta.

Hariyanto, B. (1992). Jambu Air. Penebar Swadaya; Jakarta.

Hasnelly, Sumartini, Dewi. (1997). Mempelajari

Penambahan Pengaruh

Sacharomyces Ammonium fosfat pada Pembuatan Nata Kulit Nenas. Prosiding Seminar Teknologi Pangan.

Hasnelly, Z. (1997). Kebutuhan Nitrogen. Balai Pengkajian Teknologi Pertanian; Bangka Belitung.

\section{JAGANNATH,}

A. MANJUNATHA S.S., N. RAVI and P.S. RAJU. (2011). The Effect Of Different Substrates And Processing Conditions On The Textural Characteristics Of Bacterial Cellulose (Nata) Produced By Acetobacter Xylinum. Journal of Food Process Engineering. Volume34, Issue3 593-601.

Jagannath, A., Kalaiselvan, A., Manjunatha, S.S. Raju P. S. and Bawa A. S. (2008). The effect of $\mathrm{pH}$, sucrose and ammonium sulphate concentrations on the production of bacterial cellulose (Nata-de-coco) by Acetobacter xylinum. World Journal of
Microbiology

and Biotechnology.

Mario, J. Simirgiotis ${ }^{\mathrm{a}}$, SeijiAdachi $^{\mathrm{b}}$, SatoshiTo, ${ }^{b}$ HuiYang ${ }^{a}$, Kurt A.Reynertson ${ }^{c}$ Margaret J.Basile $^{\mathrm{d}}$, Roberto R.Gil ${ }^{\mathrm{e}}$, I. BernardWeinstein ${ }^{\mathrm{b}}$, Edward J.Kennelly. (2008). Cytotoxic chalcones and antioxidants from the fruits of Syzygium samarangense (Wax Jambu). Food Chemistry. Volume 107, Issue 2, Pages 813-819. Published by Elsevier.

Muchtadi, Tien R. (1997). Petunjuk Laboratorium Teknologi Proses Pengolahan Pangan. PAU Pangan dan Gizi IPB. Bogor.

Muchtadi, Tien R. (1997). Nata De Pina. Media Komunikasi dan Informasi Pangan Nomer 33 Volume IX 1997.

$$
\begin{array}{lr}
\text { Nainggolan, J. 2009. } & \text { Kajian } \\
\text { pertumbuhan } & \text { Bakteri } \\
\text { Accetobacter sp. } & \text { Dalam } \\
\text { Kombucha-Rosela } & \text { Merah } \\
\text { (Hibiscus sabdariffa) pada Kadar } \\
\text { Gula dan Lama Fermentasi yang } \\
\text { Berbeda. (Tesis). Medan : } \\
\text { Universitas Sumatera Utara. }
\end{array}
$$

Pertiwi, Meranti D, Djoko, P. Djafar, S. (2012). Pengaruh Perbedaan Jenis Lahan Dan Terapan Budidaya Terhadap Produksi Jambu Air Merah Delima. Jurnal Ilmu Pertanian.Vol. 15 No.2, 2012 : 61 $-68$

Poedjiadi. Anna. (1994). Dasar-dasar Biokimia. UI-Press; Jakarta.

Pujiastuti, Eny. (2015). Jambu Air Eksekutif. Trubus Swdaya. Jakarta 
Rahayu, S. E. Erni, H, Ngatirah, dan Tyas Utami. (2001). Ketahanan dan Viabilitas Probiotik Bakteri Asam Laktat Selama Proses Pembuatan Kultur Kering dengan Metode Freeze dan Spray Drying. Jurnal Teknologi dan Industri Pangan, Vol 12, No 2, hal:1.

Rahayu, Endang S. (1993). Bahan Pangan Hasil Fermentasi. : Pusat Antar Universitas Pangan dan Gizi UGM; Yogyakarta.

Rahmat, Rukmana. (1999). Usaha Tani Pisang. Kanisius; Yogyakarta.

Rukmana, R. 1997. Jambu Air (Tabulampot). Kanisius. Yogyakarta.

Samad, M. Yusuf. (2006). Pengaruh Penanganan Pasca Panen Terhadap Mutu Komoditas Hortikultura. Jurnal Sains dan Teknologi Indonesia. Vol. 8 No. 1 April 2006 Hlm. 31-36. Jakarta

Sudarmadji S., Bharyono, dan Suharti. (1997). Prosedur Analisa untuk Bahan Makanan dan Pertanian. Liberty; Yogyakarta.

Sudarmadji, Slamet. (1989). Mikrobiologi Pangan. PAU Pangan dan Gizi UGM; Yogyakarta.

Sumeru, Ashari. (1995). Hortikultura Aspek Budidaya. UI Press; Jakarta.

Syukroni, Ikbal. Kiki Yuliati dan Ace Baehaki. (2013). Karakteristik Nata De Seaweed (Eucheuma cottonii) Dengan Perbedaan Konsentrasi Rumput Laut Gula Aren.

Jurnal FishtecH. Volume 2 nomor 1.
Tirtawanata, T.C. (1999). Makanan dalam Perspektif Al-Qur'an dan Ilmu Gizi. Jakarta. Balai Penerbi FKUI.

Widarto. (2001). Teknologi Tepat Guna. Disampaikan pada pembekalan mahasiswa peserta KKN Universitas Negeri Yogyakarta.

Widodo, Pudji. (2015). Jambu Semarang dan Jambu Air. Tim BPU Percetakan dan Penerbitan Universitas Jendral Sudirman. Purwukerto.

Zalita, H.R, Utami, S.H, dan Dwi, L. (2017). Survei Kebutuhan Masyarakat Pengrajin Olahan Buah Di Kabupaten Jombang Tentang Pembuatan Nata Dari Jambu Darsono Sebagai Dasar Pengembangan Media Pembelajaran Booklet. Seminar Nasional. UM

ZHANG Fu-ping1,LIU Zhi-cong1,CHEN Wei-xin1,CHEN Huanbin2,CHEN Xue-fen2. (2012). Study on the Characteristic of Polyphenol Oxidase in Syzygium samarangense Fruit and Its Inhibitor. Journal Hubei Agricultural Sciences. 